\title{
Impacts of COVID-19 on the Agri-food Sector: Food Security Policies of Asian Productivity Organization Members
}

\author{
Shaikh Tanveer Hossain* \\ Date Received: 03rd May 2020 / Date Accepted: 05th May 2020
}

\begin{abstract}
Purpose : Despite demographic differences, agriculture is a major source of socioeconomic stability among APO member economies. This report highlights potential risks faced by their agri-food sectors due to the COVID-19 pandemic and outlines the responses and policy actions each member is taking to address threats to food security and prevent hunger.
\end{abstract}

Research Method: Publicly available information was synthesized, and insights from 19 individuals working in agriculture or agri-food-related areas in the public or private sectors or academia in APO member countries were obtained.

Findings : Imminent, medium- and long-term food security challenges due to COVID-19 vary among APO member countries. However, through the implementation of key policies, many stress the need for critical agricultural inputs, such as fertilizers and safe, quality seeds, to meet seasonal crop calendars. The longer COVID-19 containment measures stay in place, the more challenging the recovery process will be for ensuring smooth food production, accessibility to staple food and nutrition and trade among countries.

Originality / Value : Provides consolidated insight into policies and actions taken by APO member economies to mitigate the impacts of COVID-19 on food security and the agri-food sector.

Keywords: Agriculture, Agri-food sector, Asian Productivity Organization, Food security, Policy

\section{INTRODUCTION}

COVID-19 is an infectious disease caused by SARS-CoV-2, the most recently discovered coronavirus. The COVID-19 outbreak that began in December 2019 in Wuhan, Hubei Province, China, has quickly spread to more than 210 countries and territories. As of 3 May 2020, there had been more than 3.3 million coronavirus cases and 233,000 deaths worldwide. The World Health Organization (WHO) officially declared the coronavirus a global pandemic. The virus is disrupting fundamental systems and industries, including agriculture and food systems, and endangering the livelihoods of workers. The Food and Agriculture Organization of the United Nations (UNFAO) indicated that among populations who are already malnourished, weak and vulnerable to disease, a 'crisis within a crisis' could emerge, in which the current health crisis will be compounded by a hunger crisis
(Food and Agriculture Organization, 2020a). In a vicious feedback loop, that would leave more people weaker and more vulnerable to the virus. Even before COVID-19, 113 million people were struggling with severe acute food insecurity due to pre-existing shocks or crises. This means that they were already on the extreme end of the hunger spectrum: weak and less well-equipped to fend off viral infection.

COVID-19 is a health crisis, but it could also lead to a food security crisis if proper measures are not taken. The world is already facing food and nutrition security challenges. According to the UNFAO (2020a), more than 820 million people

\footnotetext{
Agriculture Division, Asian Productivity Organization, Tokyo, Japan.

stanveer@apo-tokyo.org
}

DD ORCID http://orcid.org/0000-0003-4186-2873 
across the globe are suffering from hunger. Global outbreaks like Ebola, SARS and MERS all had negative impacts on food and nutrition security, particularly for vulnerable populations including children, women, the elderly, and the poor. When Ebola began to hit Guinea, Liberia and Sierra Leone in 2014, domestic rice prices increased by over $30 \%$; the price of cassava, a major staple in Liberia, increased by $150 \%$ (Fan, 2020). The 2014 Ebola epidemic also led to an increase in abandoned agricultural areas and reduced fertilizer use in West Africa (Fan, 2020). If the COVID-19 pandemic continues into the critical spring planting period, the production of staple food crops such as wheat, rice and vegetables will be affected, as it is unclear if agricultural inputs can be distributed in a timely manner. If staple production is affected, the impact on food security could be grave (Fan, 2020).

Food security consists of two key elements: economic access, or whether people have enough money to buy food; and physical access, or whether people are able to find available food. The COVID-19 pandemic may cause a food crisis in developing countries due to ongoing and arising issues associated with both economic and physical accessibility. The Global Food Security Index (GFSI) uses 34 qualitative indicators across the three core issues of affordability, availability and quality and safety to set a quantitative food security benchmark (Table 01). On 31 March 2020, as the world was struggling to combat the COVID-19 pandemic, the FAO, WHO and World Trade Organization (WTO) issued a joint statement that uncertainty about food availability could spark a wave of export restrictions, creating shortages on the global market (Dongyu, Adhanom Ghebreyesus and Azevedo, 2020).

Many Asian Productivity Organization (APO) member countries have adopted trade measures to mitigate the effects of COVID-19 on food security (Table 02). Food shortages could lead to price surges, making it more difficult for people in poor countries to buy food. Moreover, the COVID-19 pandemic continues to have widespread impacts on workforces globally. Migrant workers are among those bearing the brunt of the crisis.

Table 01: 2019 Global Food Security Index (GFSI) rankings (covering 113 countries) of APO member countries (The Economist, 2020).

\begin{tabular}{ccccccc}
\hline $\begin{array}{c}\text { Global } \\
\text { Ranking }\end{array}$ & $\begin{array}{c}\text { APO } \\
\text { Ranking }\end{array}$ & $\begin{array}{c}\text { APO Member } \\
\text { Country }^{\mathrm{a}}\end{array}$ & $\begin{array}{c}\text { Overall score } \\
(0-100)\end{array}$ & $\begin{array}{c}\text { Affordability } \\
(0-100)\end{array}$ & $\begin{array}{c}\text { Availability } \\
(0-100)\end{array}$ & $\begin{array}{c}\text { Quality \& Safety } \\
(0-100)\end{array}$ \\
\hline 1 & 1 & Singapore & 87.4 & 95.4 & 83 & 79.4 \\
21 & 2 & Japan & 76.5 & 82.4 & 71 & 76.7 \\
28 & 3 & Malaysia & 73.8 & 81.7 & 67.7 & 70.6 \\
29 & 4 & Republic of Korea & 73.6 & 75.8 & 71.2 & 74.9 \\
41 & 6 & Turkey & 69.8 & 74.7 & 64.8 & 71.1 \\
52 & 7 & Thailand & 65.1 & 77.1 & 58.7 & 52.6 \\
54 & 8 & Vietnam & 64.6 & 75.1 & 59.7 & 51.7 \\
62 & 9 & Indonesia & 62.6 & 70.4 & 61.3 & 47.1 \\
64 & 10 & Philippines & 61 & 68.9 & 57.7 & 50.3 \\
66 & 11 & Sri Lanka & 60.8 & 65 & 60 & 52.4 \\
72 & 12 & India & 58.9 & 64.2 & 58.4 & 47 \\
78 & 13 & Pakistan & 56.8 & 63.2 & 55.7 & 43.6 \\
79 & 14 & Nepal & 56.4 & 58.5 & 55.4 & 53.7 \\
83 & 15 & Bangladesh & 53.2 & 60.4 & 54.8 & 30.6 \\
90 & 16 & Cambodia & 49.4 & 56.7 & 48.1 & 34.6 \\
92 & 17 & Lao PDR & 49.1 & 55.5 & 47.6 & 37.4 \\
\hline
\end{tabular}

${ }^{a}$ Data for Fiji, Mongolia, ROC and IR Iran are not available. 
Table 02: Overview of COVID-19 pandemic-related trade measures adopted by APO member economies as of 24 April 2020 (Macmap, 2020).

\begin{tabular}{|c|c|c|}
\hline Country & Type of Measure & Details \\
\hline Cambodia & Export prohibition & $\begin{array}{l}\text { Some rice and fish exports banned to ensure local food } \\
\text { security during the coronavirus crisis }\end{array}$ \\
\hline India & $\begin{array}{l}\text { Licensing or permit } \\
\text { requirements to export }\end{array}$ & $\begin{array}{l}\text { Rice traders suspended signing new export contracts } \\
\text { amid the nationwide lockdown, although no move by the } \\
\text { government to ban exports }\end{array}$ \\
\hline Indonesia & $\begin{array}{l}\text { Suspension of certification } \\
\text { requirements }\end{array}$ & $\begin{array}{l}\text { Temporary elimination of import certification } \\
\text { requirements on imports of onions and garlic }\end{array}$ \\
\hline Singapore & $\begin{array}{l}\text { Tariff reductions, increased } \\
\text { quotas }\end{array}$ & $\begin{array}{l}\text { Elimination of import tariffs and other duties on certain } \\
\text { essential certain goods including agricultural products }\end{array}$ \\
\hline Thailand & Export prohibition & Ministry of Commerce banned exports of chicken eggs \\
\hline Turkey & $\begin{array}{l}\text { Licensing or permit } \\
\text { requirements to export }\end{array}$ & $\begin{array}{l}\text { Lemons subjected to export control amid rising domestic } \\
\text { demand due to the coronavirus pandemic }\end{array}$ \\
\hline Vietnam & Export quotas & $\begin{array}{l}\text { Quantity of rice exports controlled based on regular } \\
\text { consultations between the Ministry of Industry and Trade } \\
\text { and Prime Minister }\end{array}$ \\
\hline
\end{tabular}

Transportation delays or cancellations may hamper the timely supply and application of agricultural inputs. Many countries are dependentonimported farminputs likepesticides and fertilisers, as well as on international seed programmes for securing safe, high-quality seeds. Without international support or strong domestic policies, countries face barriers to obtaining the necessary agricultural inputs needed for sustaining agricultural productivity and food security.

Labour is an essential component in agriculture value chains from farm to fork. However, restrictions on the movement of people across local, state and international borders have already impacted harvesting and transplanting of key crops, especially rice. Rice is an essential staple food for much of the world's population. Rice-exporting countries, perhaps in anticipation of reduced future production, have started to restrict export tonnage. In the eastern parts of Bangladesh, where rice is the most important crop in low-lying areas, famers are struggling with the lack of seasonal farm labour. Due to travel restrictions, labourers are unable to move from one place to another, and in some cases, farmers cannot return to their fields. Disruptions at these stages of agriculture value chains could have serious long-term impacts. In the food-processing industry, COVID-19 could potentially affect the seasonal migrant workforce needed for jobs such as fruitpicking. Domestic policies that impose mobility restrictions mean that grocery shopping trips are infrequent, while labour shortages and limited transportation affect supply.

Moreover, panic-buying of food and other essential items has hit many places worldwide. Such panic exacerbates temporary food shortages, leading to price spikes and market disruptions. Domestic and international trade disruptions may in turn trigger food panics and trade system breakdowns. At present, supermarkets and grocery stores in many countries may not feel the immediate impacts due to strong food storage infrastructure. However, the situation may become critical if supply chains are disrupted or food production industries cannot operate at full swing due to labour shortages, lack of raw materials or quarantines. These will severely affect smallscale companies that are often major suppliers of domestic dry foods like sweets and snacks. 


\section{MATERIALS AND METHODS}

The APO is a non-political, non-profit, nondiscriminatory intergovernmental organisation established in 1961. It now has 21 member economies in the Asia-Pacific region: Bangladesh, Cambodia, Republic of China, Fiji, Hong Kong, India, Indonesia, Islamic Republic of Iran, Japan, Republic of Korea, Lao PDR, Malaysia, Mongolia, Nepal, Pakistan, Philippines, Singapore, Sri Lanka, Thailand, Turkey and Vietnam. Despite their linguistic, economic and cultural differences, agriculture is a major source of economic and social stability at the local, regional, national and international levels. This paper highlights the potential risks faced by the agri-food sector in APO member countries due to the COVID-19 pandemic. It also outlines the immediate responses and policy actions each member country had taken at the time of writing to address threats to food security and prevent hunger.

Due to the evolving nature of the COVID-19 pandemic, this report is a synthesis of information received from individuals working in the public or private sectors in APO member countries. These individuals have translated publicly available information to share knowledge, information and experiences in dealing with COVID-19. The material and information in this paper were correct at the time of writing.

\section{RESULTS AND DISCUSSION}

\section{Bangladesh}

Agriculture in Bangladesh is divided into three major sub-sectors: crops, livestock and fisheries. Although the level of production in these sectors during the rabi season (October to March) was not significantly impacted by COVID-19, the marketing and distribution of produce, such as vegetables, fruit, eggs, broiler meat and milk, have been hampered, mainly due to the lack of timely marketing and decreased demand from consumers as a result of decreased affordability. Many dairy farmers are struggling to sell milk due to the countrywide lockdown. Over the last few months, around 12 to 15 million litres of milk remained unsold every day, resulting in daily losses of BDT570 million (BDT84 = USD1). Dairy farmers are sometimes forced to sell milk at TBDT10 per litre in some regions, while in other regions they find it difficult to sell at all. They have even resorted to pouring unsold milk on the streets.

Poultry meat is being sold at BDT70 per kg, while the cost of production is estimated to be BDT100 per kg. Retail egg prices are BDT4 each, although they cost BDT6.5 to produce. The Bangladesh Poultry Industries Central Council (BPICC) reported that less chicken meat and fewer eggs were available on the market because of countrywide lockdowns, causing pressure on production, distribution and retail sales. Hatchery owners have also struggled to sell their day-old chicks. According to BPICC estimates, poultry industry losses totalled approximately BDT2,500 crore (1 crore $=$ BDT10 million) in March 2020. April 2020 was projected to see similar losses due to the national lockdown that started from 26 March 2020. Bangladesh was projected to lose USD20 million in vegetable export earnings due to the COVID-19 pandemic, with the overall agriculture and food sector facing losses of BDT2 billion a day during the lockdown. As of late April 2020, about BDT56 billion had been lost to the coronavirus fallout.

The Government of Bangladesh has launched a revolving refinance scheme of BDT5,000 crore for farmers working in the crop, dairy, poultry, horticulture and aquaculture industries. Subsidies of variable amounts have been allocated to farmers to help acquire agromachinery to reduce the cost of production and increase crop yields. The Ministry of Agriculture immediately allocated 800 combine harvesters and 400 reapers to support the boro (rice) harvest in the Haor region (northeast Bangladesh) at a cost of BDT100 crore. The government will procure an additional two lakh $(1$ lakh $=100,000)$ metric tonnes of rice from farmers and millers at fixed prices (BDT26 per $\mathrm{kg}$ of paddy and BDT36 per $\mathrm{kg}$ of milled rice), which are anticipated to above market prices in a normal year. The government decided to procure 11.5 lakh metric tonnes of boiled and 
non-boiled rice and 6 lakh metric tonnes of paddy during the current boro season. This will maintain food reserves and ensure that farmers receive remunerative prices, allowing rice production in subsequent seasons to be sustained.

The Government of Bangladesh is also distributing aid packages, containing rice, potatoes, pulses, oil, onions and salt to those in need across the country to cope with COVID19-related lockdowns. It also oversees open market sales of rice at BDT10 per $\mathrm{kg}$ in the capital and major cities across the country.

\section{Cambodia}

In Cambodia, farmers face several challenges. In addition to produce distribution issues, a declaration of the Royal Government of Cambodia permits only the export of fragrant rice, while other types are reserved for domestic sales. These policies have the potential to decrease agricultural products in Cambodia and adversely impact the livelihoods of farmers during and after the COVID-19 pandemic (World Farmers' Organization, 2020).

On 25 February 2020, Cambodia announced that it would provide tax breaks and tax holidays for numerous domestic industries, including agriculture (Medina, 2020). To support the agriculture sector, the government is allocating USD50 million in the form of low-interest loans to help SMEs. Funds will be distributed through the state-owned Rural Development Bank (RDB) with the goal of increasing local production capacity (Medina, 2020). The Ministry of Agriculture, Forestry and Fisheries has also taken measures to mitigate any potential negative impacts on the livelihoods of those living in rural areas, especially smallholder farmers (Food and Agriculture Organization, 2020b). Further policies target job creation and income generation in rural households, as well as providing training on agricultural techniques to support improvements in harvesting and food production and utilising market linkages more actively.

\section{Fiji}

The Ministry of Agriculture of Fiji is assisting farmers and households to engage in productive agricultural activities to enhance food and nutrition security. Initiatives such as the distribution of home gardening seed packages, securing household and village rice production and supply programmes, supporting village nutritional programmes and a poultry meat supplementation programme, expanding medium and large-scale agricultural production, providing farm response packages, establishing large commercial ventures as well as an orchard and nursery programme, improving crop genetics, and establishment of medium-to-large livestock farms are among current measures.

The Fijian government has provided an additional USD1 million to the Ministry of Agriculture to bolster food security and another USD1 million for rice planting to support staple agricultural crop production impacted by COVID-19. The New Farm Support package aims to boost production of short-term crops by providing seeds and planting materials to farmers (Government of Fiji, 2020). The Ministry of Agriculture has made arrangements to ensure that Fijians have access to adequate food. The Agriculture Marketing Authority (AMA) has agreed to buy from all suppliers and deliver the produce to the vendors of Lautoka, Fiji's second-largest city. The AMA has also set up consumer sales booths on opposite sides of Lautoka. Suppliers at the booths are paid in cash for sales of their produce to the AMA (Food and Agriculture Organization, 2020b).

\section{India}

The COVID-19 pandemic has disrupted some activities in agriculture and its supply chains in India. The low availability of migrant labour is interrupting harvesting activities, particularly in the northwest where wheat and pulses are major crops. Agricultural commodity prices have declined due to the closure of hotels, restaurants, sweetshops, and teashops. Meanwhile, poultry farmers have been badly hit due to misinformation, particularly on social 
media, that chickens are carriers of COVID-19. The nationwide lockdown has also affected agricultural activities and supply chains through input distribution, harvesting, procurement, transportation, marketing and processing of farm produce. Shortages of fertilisers, plant protection chemicals, veterinary medicines and other inputs could also affect agricultural production.

The Government of India announced that most agricultural activities are on the essential activities list and thus agricultural field workers, farming operations, agencies engaged in procurement of agriculture products under state governments or the Agriculture Produce Market Committee, inter- and intra-state movement of harvesting- and sowing-related machinery and manufacturing, and units packaging fertilisers, pesticides and seeds are excluded from lockdown restrictions.

Importantly, the government has directed public and private seed-sector companies to provide high-quality seeds to farmers for the upcoming planting season. Additional grain allotments to registered beneficiaries will be available for a 3-month period. Cash and food assistance to persons engaged in the informal sector, mostly migrant labourers, is available under the newly created Prime Minister Citizen Assistance and Relief in Emergency Situations (PM-CARES) fund.

The government emphasises continuous monitoring of agricultural supply chains to ensure that they function at the capacity required to meet the food security demands of low- to noincome populations. Other initiatives allow for the free movement of fruit and vegetables, and farmers' shandies (open-air market stalls) and weekly shandies will continue to support the sale of vegetables. Nutrition programmes like Integrated Child Development Services (ICDS), mid-day meals, and anganwadis (rural childcare centres) are recognised as essential services to provide rations and meals to recipients at home. The government has transferred INR500 per month to the bank accounts of 200 million women via the Jan Dhan financial inclusion programme.

\section{Indonesia}

The outbreak of COVID-19 has forced many countries to protect their food security. The Indonesian government has re-arranged the national budget to cope with the COVID-19 pandemic. The newly proposed national budget relies heavily on the Ministry of Health and National Disaster Mitigation Agency to increase incentives for affected communities. The national budget for the Ministry of Agriculture (MOA) was revised downward from the original allocation, and policies for food security put in place in anticipation of the impact of the COVID-19 pandemic, accelerate a labour-intensive programme and maintain the availability of staple foods.

To ensure the availability and accessibility of food, the MOA has coordinated with provincial agencies to create the Pasar Mitra Tani (Farmers' Cooperative Market) (BKP, 2020). Creating the Pasar Mitra Tani is a key initiative to increase logistical efficiency, as well as lower costs and time associated with distribution (BKP, 2020). Policies have been implemented to provide staple food (rice and corn) for 267 million people and accelerate exports of palm oil, cacao, coffee, pepper, nutmeg and ginger to support economic sustainability (Koin, 2020). Moreover, the government is focusing on farmers' cooperative markets to shorten supply chains while aiding famers (Pertanian, 2020).

\section{Islamic Republic of Iran}

The Iranian Ministry of Agriculture is assessing and responding to the potential impacts of COVID-19 on lives and livelihoods, food trade, markets, food supply chains and livestock. In order to support farmers and gardeners, the ministry has called for action to solve transportation issues to ensure timely delivery of seeds, paddy rice and livestock inputs through coordination with relevant institutions. Food security is the main emphasis of the Ministry of Agriculture.

To increase the farmers' cash flow, crisis management authorities under the government will increase the advances ofdirect payments. The government is providing food, loans, sanitisers, 
sprayers and other necessary equipment to farmers. Community kitchens are operating and delivering essential food supplies. The Ministry of Agriculture is focused on understanding and mitigating the pandemic's impact on food and agriculture, safeguarding the food security and livelihoods of the most vulnerable, identifying the origins and spread of the coronavirus and providing necessary information and cautionary guidelines to farmers on personal hygiene and possible transmission routes to avoid infection risks.

\section{Japan}

Although the Ministry of Agriculture, Forestry and Fisheries reported that Japan's food supply is secure (United States Department of Agriculture, 2020c), the self-sufficiency rate has been at around $40 \%$ for a number of years (Japan Times, 2015). The COVID-19 pandemic has impacted the food service and retail industries, particularly restaurants and supermarkets. School closures have disrupted supply chains for national school lunch programmes, while shifts in consumer spending have impacted SMEs, especially those involved in importing, wholesale and distribution. To cope with the effects of COVID-19, the Government of Japan announced a JPY108 trillion (USD989 billion) economic stimulus package, equal to approximately $20 \%$ of GDP (Takeo, 2020). The stimulus is designed to help families who have lost significant income, small business owners and Japanese corporations (Food and Agriculture Organization, 2020b).

\section{Lao PDR}

Despite strict entry regulations, the Lao government has permitted the transportation and flow of goods from Thailand providing that entrants comply with the 'one driver and one helper' specifications. In addition, the Prime Minister is urging people to increase agricultural production, especially small livestock and vegetables. A document issued by the Prime Minister, Decision No. 31/PM dated 2 April 2020 details policies and measures to reduce the impact of COVID-19 on the Lao economy. This decision enacts the tax and non-tax measures to take effect starting 2 April 2020 (Food and
Agriculture Organization, 2020b).

\section{Malaysia}

The agricultural, livestock and fishery supply chains are allowed to work as usual to ensure an adequate supply of vegetables, fruit, meat and fish products in Malaysia in the current lockdown period (Ministry of Agriculture and Food Industry, 2020). However, night markets, farmers' markets and roadside stalls are not allowed to operate during the movement control order (MCO). The demand for fresh produce has dropped dramatically. Effective delivery of agricultural inputs is a challenge. Many vegetable truck drivers have stopped their services due to restrictions on traffic and operating hours under the $\mathrm{MCO}$, which has affected the food production chain.

According to a survey conducted by the Department of Statistics for the period 2331 March 2020, 21.9\% of workers in the agricultural sector had lost their jobs. The Malaysian government has devised strategies to cope with the situation. The Ministry of International Trade and Industry will establish a special cabinet committee to develop strategic measures to safeguard Malaysia's economy and labour market impacted by COVID-19. The PRIHATIN Rakyat Economic Stimulus Package, worth MYR250 billion, has been released to preserve national welfare, support businesses and strengthen the national economy (New Straits Times, 2020). The Federal Agricultural Marketing Authority (FAMA) will also help vegetable growers to resolve the problem of abundant supply during the $\mathrm{MCO}$ period. The Ministry of Higher Education is offering post-COVID-19 research grants to public universities and private higher education institutions to overcome challenges in the national economy, agriculture and food security, transportation and medicine and health.

The MCO has also led to changes in spending patterns on daily needs. Conventional supply chains are no longer effective in supplying food from farm to the table. Innovations in food supply chains have a role to play during and after the MCO to ensure the supply of highquality, safe food at affordable prices. 


\section{Mongolia}

The Minister for Food, Agriculture and Light Industry of Mongolia approved a risk management plan for the food, agriculture and light industry sectors. While there are as yet no significant negative impacts on the livestock, crop and tourism sectors, this may change as the COVID-19 pandemic worsens. International trade has dropped by $21.3 \%$, mainly due to declines in exports to and imports from China by $24.4 \%$ and $8.6 \%$, respectively (Food and Agriculture Organization, 2020b).

\section{Nepal}

Using strategically placed fleets of mini trucks, the supply and distribution of daily essentials in Nepal have been minimally hampered so far. Around 15 mini trucks in Kathmandu, and seven each in Bhaktapur and Lalitpur, are assisting with the logistical transport of rice, grams, cooking oil, salt, potatoes and onions. The Nepalese government has decided to reopen its key border points with China in order to ease the supply of essential goods during the time the country is on total lockdown (Food and Agriculture Organization, 2020b).

\section{Pakistan}

Pakistan is an agriculture-based country. Agriculture contributes around $18.5 \%$ of GDP and provides $38.5 \%$ of employment to the national labour force (Government Pakistan, 2003). High-performing agriculture is key to economic growth and poverty alleviation. However, like all other sectors, agriculture is at risk in Pakistan due to COVID-19. Under the current scenario, the agriculture sector in Pakistan could be faced with three immediate issues: accessibility to food; access to agricultural inputs and supplies; and impacts on production and yield.

As a result of the COVID-19 pandemic, Pakistan may face economic and physical food security issues, especially with the global economic coronavirus recession and marketdriven food supply and demand. Similar to many other countries, COVID-19 has affected access to agricultural inputs and supplies. Crops and food supplies have their own calendars that must be followed to ensure adequate production each season. Pakistan has two distinct growing seasons: rabi, also called the winter season; and kharif, also called the summer season. As COVID-19 was first reported in winter, it is projected to extend into the summer planting season. Farmers will face acute shortages of inputs, and if available, the costs associated with acquiring inputs are likely to increase. Labour required for harvesting winter-season crops, including wheat, the staple crop of Pakistan, will be significantly reduced due to imposed restrictions on human mobility. Restrictions on the major labour-engaging sector of Pakistan's economy will result in greater unemployment.

The outbreak of COVID-19 coincided with a time when agriculture in Pakistan was already experiencing unpredictable climatic conditions, especially frequent rainfall overlapping with critical harvesting times and locust plagues. Even as an agro-based country, Pakistan is a net importer of food. Long-term persistence of the COVID-19 pandemic will destroy food availability chains across the globe. Border closures will affect international transport of food. Pakistan imports a variety of food items in both raw and processed forms, and such conditions could create a devastating situation.

On 24 March 2020, the Government of Pakistan unveiled an economic package worth PKR900 billion, equal to USD5.66 billion, to provide relief to citizens, particularly low-income groups whose livelihood has been badly affected by the COVID-19 pandemic. In this package, a total of PKR100 billion (USD612 million) was set aside for small and medium industries and the agriculture sector, while interest payments by both sectors are deferred. Additionally, PKR280 billion (USD1.76 billion) is earmarked for wheat procurement in this package.

\section{Philippines}

The Philippines, an agricultural country, has strong food-producing capability. Although agricultural activities slowed down at the onset of the COVID-19 pandemic, farmers continued growing, processing and distributing agrifishery products. However, changes were made 
to adapt to the new normal brought about by the pandemic. Many of those changes were perceived as difficult on the part of farmers, particularly in the marketing or distribution of produce due to lockdowns and regulated movements of citizens. Although sufficient food is being produced by the agri-fisheries sector, marketing as well as manufacturing of other byproducts may face difficulties due to constraints hampering food availability and distribution.

The Philippine government, through the Department of Agriculture, has instituted measures to make the agri-fisheries sector resilient and stay relevant to the needs of the present situation. Even before COVID-19 took center stage, the Rice Completeness Enhancement Fund (RCEF), for example, was already helping rice farmers. Funds are drawn from the tariff revenues of rice imports and used to directly support rice farmers and fund innovations in the rice industry. On top of the PHP65 billion budget of the Department of Agriculture for the year, the government invested an additional PHP2.8 billion in a loan facility to agri-fisheries with a maximum of PHP25,000 at no interest to help mitigate the effects of COVID-19. Occasionally, assistance is provided to farmers and farming communities in kind and in cash, especially when issues arise and the prices of goods drop drastically. Programmes like the Food Resiliency Action Plan are also in place to ensure access to safe, affordable food in Metro Manila and other large cities. Food carts and the like are being encouraged by the government to bring basic food needs to the buying community instead of customers travelling to markets where contact rates are higher and viral transmission more likely.

The government is continuously devising ways to ensure a food-secure Philippines. Assorted vegetable seeds and seedlings are provided by the government in cities and rural areas to encourage urban and home gardening. Small ruminants and poultry starters are offered to farming communities to ensure food sufficiency in the countryside. The emerging new normal in various aspects of life must be learned and embraced, including that in the food production sector, to make society sturdy and resilient in confronting COVID-19 and other potential crises in the future.

\section{Republic of China}

Authorities in the Republic of China (ROC) are confident that food and agricultural commodity stocks and supplies will last for up to 6 months in the event of further deterioration in international agricultural trade due to COVID-19 (United States Department of Agriculture, 2020d). However, the immediate effects of COVID-19 have changed domestic demand. As the start date of schools was delayed, school lunch supply chains, namely farmers and the group meal industry, have been impacted. Consumers have also reduced shopping frequency to indoor supermarkets or traditional markets. Migrant workers, who travel outside the ROC, have been temporarily barred from returning after 17 March 2020, which has impacted agricultural labour.

The Council of Agriculture (COA) of the ROC appropriated a special budget of USD245 million for rescuing and revitalising the agriculture sector, including an Agricultural Relief Loan and policies to expand e-commerce and export marketing in the agri-food sector. The COA has cooperated with 48 domestic e-commerce companies to sell 6,000 domestic agricultural products and launched a promotional discount of $10 \%$. Sales have reached USD7.1 million. The COA also provides agricultural product export incentives. The award benchmarks for 15 agricultural products, including pineapples, sugar apples, lotus mist and grouper, were announced, and their value has exceeded USD3.86 million.

There has been a push to increase consumption of agricultural products through corporate group purchases and farmers' markets. This assists farmers and grain producers to promote diversified products and improve the efficiency of transportation and lengthen the shelf-life of vegetables and fruit. Further support has been granted to create a flower promotion plan. The government has aided the fish and livestock industries, especially at the production, processing and promotion levels of the value 
chain. While in the long term, many food service operations and hotels are projected to go out of business, some argue that COVID-19 will cause food delivery platforms and e-commerce platforms to develop and flourish.

\section{Republic of Korea}

The Korean food market has been significantly impacted by the ongoing COVID-19 outbreak. Restaurant sales have dropped, while home food deliveries have increased. The price of agricultural products has increased due to reduced imports from China. Other fresh agricultural products that saw a significant price increase due to reduced supply from China include carrots (28\%), spinach (17\%) and cabbages $(6 \%)$. Prices for prepared kimchi increased by $20 \%$ as the Republic of Korea (ROK) relies heavily on imports from China. Korean retailers and restaurants are worried as it will take time for Chinese distributors and processors to resume normal operations (United States Department of Agriculture, 2020a).

Some farmers have expressed concerns about labour shortages as the outbreak has disrupted the arrival of foreign seasonal workers. However, the government announced a USD49 million loan programme to support farmers (O'Callaghan, 2020). Most of the commodities needed for daily food consumption in the ROK did not suffer severe impacts. The government therefore focused its agricultural support on other areas (United States Department of Agriculture, 2020b), such as the environmentally friendly agricultural products produced for the school lunch programme. It delayed the planned 2 March 2020 opening of schools by over a month, until 6 April 2020. Farmers that contracted to supply fresh vegetables to schools now have no outlet. The government is sponsoring market promotions at hypermarkets and asking government-related agencies to purchase these products.

The Korean Swine Association is giving away water dropwort, a leafy vegetable commonly eaten in the ROK, to consumers who purchase pork. A total of KRW60 billion (USD48.8 million) will be provided as low-interest loans to farmers unable to produce if they become subject to self-quarantine requirements due to COVID-19 exposure. There will be further measures to help exporters amidst the cancellation of export fairs and shows.

\section{Singapore}

Singapore has in place a long-term food sourcing strategy called 'Resilience' in which $90 \%$ of food is imported from over 170 geographically dispersed countries to allow substitute importing between a group of countries for each food item. Additionally, government personnel conduct sourcing trips regularly to identify new sources for imports of food that are produced under Good Agricultural Practices and food safety standards. The country currently aims to produce only $10 \%$ of its food needs through vegetables, fish and eggs.

Like other small island states, Singapore is particularly vulnerable to any disruption of food supply chains originating from exporting countries. Under normal circumstances, there are already many factors that disrupt agricultural production and food processing, such as severe weather events, natural disasters and pest or disease outbreaks. COVID-19 is therefore the 'black swan' of disruptors and is already having direct and indirect effects on the agri-food sector through its supply chains.

The immediate effects of COVID-19 have been on production, harvesting, transport, processing, wholesale, retail and consumption, caused by measures taken to limit movements of people and contacts among them. Three dimensions of food security have been affected: food availability; physical access to food; and economic access to food. The closing of all non-essential services and enterprises deprived daily wage workers of livelihoods and food purchasing power, consequently increasing hunger and under-nutrition in that population. Reduced means to deliver food to retail outlets led to temporary shortages, panic-buying by consumers and the imposition of purchase quotas for key food items, e.g., two bags of rice and 30 eggs per person per purchase. Reduced labour in the agri-food sector affects farm activities, such as harvesting current crops and inability to plant for the new season. Singapore 
also implemented an immediate governmentto-government response when Malaysia announced its lockdown on 18 March 2020 to ensure the continued flow of key food items, including vegetables (41\% import dependence), eggs (72\%), chicken (37\%) and fish (15\%).

There are numerous anticipated long-term effects. If the pandemic lasts longer than 3 to 6 months, there may be a shortage of inputs (fertiliser, seed, feed, pesticides) for agriculture and aquaculture, which will affect the replenishment of food stocks in exporting countries and on local farms. Potential shortages of labour for farming and food processing due to measures to limit the spread of the virus may occur. Agri-food enterprises going out of business and interruptions to the normal functioning of supply chains may occur because of shortages caused by export restrictions or hoarding in exporting countries, and reduced or delayed planting of new crops may lead to unreplenished stock. Price hikes are likely in Singapore because of general increases in commodity prices fueled by countries competing for reduced production, as well as declines in the nutritional intake.

Fortuitously, and in anticipation of the increasing likelihood of food supply disruptions, in March 2019 Singapore launched an initiative to increase self-sufficient nutrition by $300 \%$ by 2030 , from the current $10 \%$ to $30 \%$. This initiative is known as 'The Singapore Food Story' and was backed by an initial tranche of SGD144 million (about USD101 million) and the formation of the new Singapore Food Agency. The Singapore Food Story has three focus areas: urban agriculture and aquaculture (high-technology indoor and outdoor farms); future food (targeting alternative proteins like plant-based protein, cellular meat etc.), and food science and technology as the basis for innovations in farming and food processing and potentially developing technologies that could be exportable and used elsewhere. It currently uses a 'whole-of-system' approach to tap into all existing expertise in higher education institutes, government agencies and the private sector.

The Singapore Food Story came on the heels of other initiatives post-2011 to increase the productivity of existing conventional and high-technology urban farms. In 2020, several government research agencies were consolidated into the Singapore Institute of Food and Biotechnology Innovations, which includes a Clinical Nutrition Research Centre. This was done to allow the country to strengthen the links among agriculture, food and nutrition.

With the outbreak of COVID-19, in March 2020 the government announced a one-time intervention fund of SGD30 million to ramp up production on existing farms. As of 2019, there were 77 vegetable farms, three egg farms and 122 fish farms in Singapore. These farms met $14 \%, 10 \%$, and $26 \%$ of the island's needs for vegetables, fish and eggs, respectively, for a population of 5.6 million. In response to COVID-19, the government announced incentives to start new enterprises for growing more food within the country. For example, tenders have been called for to set up 10 rooftop vegetable farms. However, recognising its continuing reliance on overseas imports, in April 2020 Singapore signed a 'supply-chain continuity agreement' with five other countries which will likely extend to more countries.

\section{Sri Lanka}

Enforcing the necessary social distancing measures and subsequent curfews hindered the economy of Sri Lanka, including its important rural sector mainly based on agriculture and tourism. Even though the government has allowed farming to continue unrestricted, uncertainties surrounding temporary lifting of curfew hours and means of distributing essential goods to households have resulted in wastage and slowdowns in the supply and storage of perishable agricultural goods. However, tea estates, the tea smallholder sector and tea factories are operating despite curfew enforcement. Sri Lanka's tea prices rose sharply at an auction held in April amid COVID-19 curfews and a falling rupee, due to strong demand from abroad and tight supplies after dry conditions in farming areas. Unlike other export industries, tea did not see a fall in demand from foreign buyers, although volumes were down. The first automated e-auctions in place of physical auctions are now being adopted, 
changing a 137-year-old tradition in a bid to continue operations.

To address the future demand for fruit and vegetables, theSriLankanMinistryofAgriculture introduced a home gardening programme called Saubhagya Gewatta (Prosperous Home Gardens). 'From garden to table' is the principal concept behind this programme. In the midst of the COVID-19 pandemic, the Government of Sri Lanka initiated the Saubhagya National Programme on Harvesting and Cultivation on 4 April 2020 which aims to develop 1 million home gardens. It will encourage rural seed farm projects, popularise organic fertiliser use, encourage production of home crops and promote home gardens for self-consumption. The main problem is whether sufficient seeds for 1 million home gardens are available. The success of this project will mainly depend on the availability of quality seeds and planting material. The Ministry of Agriculture set up a website for this programme.

\section{Thailand}

Reductions in tourist numbers due to the COVID-19 pandemic have directly affected demand in the food sector in Thailand. Agriprice levels have decreased gradually, and imbalances in supply and demand are starting to be seen. Over the last few years, Thailand, as the kitchen of the world, has had some vacant or idle capacity in food production in both the agriculture and food industries due to enforced illegal, unreported and unregulated (IUU) policies of Western countries. The spread of COVID-19 has created panic, while countermeasures have led to unemployment, lower incomes, demand drops, and temporary or permanent closures of businesses.

However, Thailand has accumulated experience in food traceability and combatting SARS and avian flu (H5N1) in the poultry industry. The government has provided a significant financial budget, countermeasures and policies to fight COVID-19. Since food supply chains connecting farms to consumers' tables are long, the government is trying to keep connecting chains linked and operating. Therefore, food transport is permitted without time limits for both individual consumption and processing for export. When food chains are functioning, employment can be maintained, which also makes economic sense while ensuring food security and sustainability.

The Thai government announced that it will provide soft loans worth THB150 billion, with extended deadlines for payments of principal and debts, and the right to borrow from special financial institutions such as the Bank of Agriculture and Cooperatives. This package will benefit 7.2 million farming households and 3 million small-to-medium-sized enterprises (Food and Agriculture Organization, 2020b).

\section{Turkey}

The COVID-19 pandemic has been affecting Turkey since 11 March 2020 after the announcement of its first official case. Restaurants, hotels, cafes and other service providers are all closed; supermarkets, bakeries and other food retailers remain open under certain conditions. Farmers and farm workers face restrictions during this phase, although currently they can be granted permission for travel. The governorates issue permission under specific circumstances, which are listed by region or by crop. Even if transportation is strictly limited for people, goods can be transported within the country and abroad. Logistics companies are allowed to operate within the country.

As of 2019, field crops such as cereals, pulses and other cash crops like potatoes and cotton dominated Turkish plant production with 15.39 million ha $(66.7 \%$ of agricultural land plus $14.7 \%$ fallow). Horticultural crops occupied 4.32 million ha. This supplies food (and non-food) for 83.2 million Turkish citizens, 3.71 million Syrians and 3.71 million other nationalities with residence permits (as of 2020); raw material for the food, textile and other related industries; and for exports. Due to the current severe restrictions on tourism activities, the amount previously consumed by this sector is expected to flow to the domestic market as extra supply. Meat stocks are reported as adequate, whereas aquaculture products seem to have a surplus. 
Despite the specific permission issued to farmers and farm workers, many activities requiring immediate responses such as harvesting, sowing or planting seedlings are hindered in various regions. Due to the lockdowns, fresh weekly markets for fruit and vegetables have slowed down; small farmers in peri-urban areas are particularly affected in regard to market access. In Turkey, all horticultural crops except for direct sales of small farms must be sold at the wholesale markets of municipalities. Currently, fruit and vegetable demand is at very low levels in the wholesale markets. Online sales of supermarket chains or smaller food shops and greengrocers have increased.

Prices increases for inputs and a few commodities have been seen since the pandemic was declared. Government support for farming provides $75 \%$ funding for seeds of certain field crops in 21 provinces. Decreases in or exemptions from customs tax were authorised for imports of major food and feed crops such as wheat, maize, sunflower, sunflower oil and rice. The short-term effects of COVID-19 restrictions are currently noted in limited labour availability and access of small farmers to markets. More significant effects are expected to appear in summer, especially for annual crops, because the distribution of inputs, propagation material and raw material for the processing industry as well as financial capital are all significantly affected.

\section{Vietnam}

The COVID-19 pandemic has slowed global trade and disrupted supply chains. This particularly affects Vietnam, which relies on China to import raw materials for its industries and then exports finished products back to the country.

The consumer market has slowed due to border closures and limited movements. Domestic consumption has also been severely affected because of a decline in the amount of food and foodstuffs in schools, restaurants and hotels. Inventory use has also increased, causing the cost of storage, transportation and circulation of goods to rise, especially for fresh agricultural products. Enterprises have had great difficulties in managing capital with reduced revenue, including problems in capital recovery, repayment of bank loans and capital rotation to buy agricultural raw materials from farmers. Labour shortages have occurred due to enterprises delaying or reducing their production, while changing the wage mechanism and other conditions of labourers. Agricultural production is difficult due to shortages of raw materials because the source of imports is mainly China and some markets in Northeast Asia, ASEAN and the EU. This will worsen if the pandemic is prolonged.

Fruit exporters are required to submit certificates confirming that the fruit is not contaminated with COVID-19. Rising costs are seen due to changes in delivery locations and extended transport times caused by changes in the schedules of shipping companies to adhere to pandemic prevention and control regulations. Ministries, branches and localities direct, guide and support people and enterprises in stabilising production, maintaining agro-forestry and fishery supply chains, developing markets, ensuring an adequate supply of safe food for the domestic market and preparing to increase exports after the pandemic in export markets is contained.

In addition, the Ministry of Agriculture continues to coordinate with other ministries and branches to develop synchronous solutions to stabilise pork prices, promote re-plasticisation to meet domestic market demand and exports after the removal of the EU yellow card for fisheries. Overall, the pandemic will force businesses and supply chains to grow. Businesses will have to innovate and prepare for new volumes of demand, models and trends. Vietnam needs a long-term strategy, and businesses need to change and adapt to reality to continue developing agriculture and ensure food security.

Vietnam's government approved a plan to export 400,000 tons of rice in April 2020 after exports were previously suspended and another 400,000 tons in May. The quantity of rice exported is reduced by $40 \%$ in comparison with the same period in 2019 . The national rice reserve is 700,000 tons above the normal level. 
The Prime Minister emphasised that rice exports must be controlled to ensure food security for 100 million Vietnamese in the current context (Food and Agriculture Organization, 2020b).

\section{CONCLUSION}

COVID-19 is a global issue requiring coordinated regional and global responses. It is critical that policies and initiatives target both the agriculture and agri-food sectors to support essential businesses and local, regional, national and international supply chains. Moreover, policies must ensure that both the economic and physical elements of food security are met amidst the COVID-19 pandemic. Without coordinated, sustained efforts, there is no doubt that potential risks associated with food insecurity during and after COVID-19 will arise, which could in turn lead to a 'crisis within a crisis'. Through publicly available information and insights from key individuals engaged throughout the public and private sectors in APO member economies, this survey report shows that imminent, medium- and longterm food security challenges due to COVID-19 vary markedly among APO members.

This paper contributes to current COVID-19 research by not only exploring the links between global health pandemics and food security, but also by providing insights into policies and actions taken by APO member economies to mitigate the impacts of the pandemic on food security and the agri-food sector. The longer COVID-19 containment measures stay in place, the more challenging the recovery process will be for ensuring smooth food production, accessibility to staple food and nutrition and trade among countries.

\section{ACKNOWLEDGMENTS}

The author would like to thank APO SecretaryGeneralDr.AKP Mochtan for his encouragement and support throughout this project. Further thanks are due to Mr. Tadahisa Manabe, Head of the APO Agriculture Division, as well as other divisional colleagues for their support and cooperation. The efforts and contributions of informants from APO member countries, who are listed below, and other sources are very much appreciated. Finally, the author is grateful to Ms. Sarah Frances Strugnell, current APO Secretariat intern and master's degree candidate at the University of Tokyo, Japan, for all her assistance and support in preparing this manuscript.

\section{Contributors}

Bangladesh: Professor Dr. Mohammad Jahangir Alam, Faculty of Agricultural Economics and Rural Sociology, Bangladesh Agricultural University

Cambodia: Mr. Monorum Chhoun, Project Manager, Bayon Heritage Holding Group,

Fiji: Ms. Arpana Pratap, Team Leader Member Capacity, Pacific Islands Development Forum, Suva

India: 1) Dr. Rajesh Sharma, Professor of Agricultural Economics, SK Rajasthan Agricultural University, Bikaner; 2) Dr. S. Senthilnathan, Assistant Professor (Agricultural Economics) and Assistant Public Relations Officer, Tamil Nadu Agricultural University, Coimbatore

Islamic Republic of Iran: Mr. Jamshid Pishkar, Director, Department of the Presidency and Public Relations, Institute of Agricultural Education and Extension, Ministry of Agriculture

Indonesia: Dr. Wahyudi David, Food Science and Technical University Bakrie, Jakarta

Malaysia: Dr. Lau Wei Hong, Associate Professor, Faculty of Agriculture, Universiti Putra Malaysia

Pakistan: 1) Dr. Zuhair Hasnain, Assistant Professor, PMAS Arid Agriculture University, Islamabad; 2) Ms. Areefa Azam, Founder \& Chief Executive, Reef's Organic Box, SME \& Agribusiness Consultant; 3) Dr. Muhammad Faheem Akbar, Assistant Professor, Department of Agriculture and Agribusiness Management, University of Karachi 
Philippines: Dr. Norman Gonzales de Jesus, Director/Professor VI, Pampanga State Agricultural University

Republic of China: Dr. Song Hung Yi, Section Chief, Agriculture \& Food Agency Council, Agriculture Executive Yuan, Taipei

Singapore: Prof. Paul Teng Piang Siong, Adjunct Senior Fellow, Centre for Non-Traditional Security Studies, RSIS, Nanyang Technological University

Sri Lanka: Prof. Rohana Pandukabhaya Mahaliyanaarachchi, Department of Agri Business Management, Faculty of Agricultural Sciences, Sabaragamuwa University
Thailand: Mr. Sankrit Cheawchan, Assistant Vice President (Former), Better Foods Co., Ltd.

Turkey: Prof. Dr. Uygun Aksoy, Department of Horticulture, Ege University

Vietnam: 1) Ms. Cao Thị Minh Hue, Agro Processing and Market Development Authority (Agrotrade), Ministry of Agriculture and Rural Development, Hanoi; 2) Dr. Nguyen Thi Bich Thuy, Director, International Cooperation Office, and Head, Department of Postharvest Technology, Faculty of Food Science and Technology, Vietnam National University of Agriculture, Hanoi

\section{REFERENCES}

BKP. (2020). Pasar Mitra Tani di Semua Provinsi Siap Jaga Pasokan dan Stabilitas Pangan di Tengah Pandemi Covid-19. (Farmers' Markets in All Provinces Ready to Maintain Supply and Stability of Food in the Middle of Pandemic Covid-19. Ministry of Agriculture, Food Security Agency (English version). DOI: https://doi.org/10.31752/idea.2020.17

http://bkp.pertanian.go.id/blog/post/pasar-mitra-tani-di-semua-provinsi-siap-jaga-pasokan-danstabilitas-pangan-di-tengah-pandemi-covid-19. 19.4.20.

Dongyu, Q., Adhanom Ghebreyesus, T. and Azevedo, R. (2020). Mitigating impacts of COVID-19 on food trade and markets.

http://www.fao.org/news/story/en/item/1268719/icode/. 19.4.20.

The Economist. (2019). The Global Food Security Index (GFSI). https://foodsecurityindex.eiu. com/country.23.4.2020.

Fan, S. (2020). Preventing global food security crisis under COVID-19 emergency. https://www. ifpri.org/blog/preventing-global-food-security-crisis-under-covid-19-emergency._20.4.2020. DOI: https://doi.org/10.2499/p15738coll2.133678

Food and Agriculture Organization, United Nations (UNFAO). (2020a). COVID-19: Our hungriest, most vulnerable communities face "a crisis within a crisis." http://www.fao.org/news/story/ en/item/1269721/icode/. 20.4.2020.

Food and Agriculture Organization, United Nations (UNFAO). (2020b). Food and Agriculture Policy Decision Analysis (FAPDA) Tool.

http://www.fao.org/in-action/fapda/tool/index.html\#main.html_.20.4.20.

Government of Fiji. (2020). Statement by Minister for Agriculture Dr. Mahendra Reddy on Food Security and Agriculture Growth and Expansion Plan, 20 April 2020.

https://www.fiji.gov.fj/Media-Centre/Speeches/STATEMENT-BY-THE-MINISTER-FORAGRICULTURE-DR-MAHEN. 27.4.20. 
Government of Pakistan, Ministry of Finance. (2003). Chapter 2. Agriculture.

http://www.finance.gov.pk/survey/chapters_19/2-Agriculture.pdf. 27.4.2020.

Japan Times. (2015). Nation's food self-sufficiency rate. https://www.japantimes.co.jp/ opinion/2015/04/01/editorials/nations-food-self-sufficiency-rate/\#.XqqfuSkzbIU. 30.4.20.

Koin. (2020). Bappenas usulkan kebijakan pemenuhan pangan dalam negeri selama pandemi Covid-19.

https://koin24.id/bappenas-usulkan-kebijakan-pemenuhan-pangan-dalam-negeri-selamapandemi-covid-19/. 20.4.20(

Macmap. (2020). COVID-19 Temporary Trade Measures.

https://www.macmap.org/covid19. 24.4.20.

Medina, A. F. (2020). https://www.aseanbriefing.com/news/cambodia-issues-regulationsbusinesses-impacted-covid-19-eba/.20.4.20.

New Straits Times. (2020). PM's full speech on Prihatin Economic Stimulus Package.

https://www.nst.com.my/news/nation/2020/03/578956/pms-full-speech-prihatin-economicstimulus-package. 19.4.20.

O’Callaghan, L. (2020). Covid-19 changes Korean consumption.

http://www.fruitnet.com/asiafruit/article/181269/covid-19-changes-korean-consumption. 20.4.20.

Pertanian. (2020). Kementerian Pertanian Republik Indonesia.

https://www.pertanian.go.id/home/?show=page\&act=view\&id=99. 20.4.20.

Takeo, Y. (2020). Japan's virus stimulus package to come in two phases. https://www.bloomberg. com/news/articles/2020-04-06/japan-s-virus-stimulus-package-to-come-in-two-phasesdocuments-k8nuj552. 15.4.20.

United States Department of Agriculture, Foreign Agricultural Services. (2020a). South Korea: COVID-19 Impact on Korean Food Retail Market.

https://www.fas.usda.gov/data/south-korea-covid-19-impact-korean-food-retail-market.19.4.20.

United States Department of Agriculture, Foreign Agricultural Services. (2020b) South Korea: Additional Impact on Korean Agriculture and Food Situation.

https://www.fas.usda.gov/data/south-korea-additional-impact-korean-agriculture-and-foodsituation. 19.4.20.

United States Department of Agriculture, Foreign Agricultural Services. (2020c). Japan: COVID-19 Impacts on Food Distribution in Japan.

https://www.fas.usda.gov/data/japan-covid-19-impacts-food-distribution-japan. 19.4.20.

United States Department of Agriculture, Foreign Agricultural Services. (2020d). Taiwan: Taiwan Confident in Food Stocks as COVID-19 Disrupts International Trade. 
https://www.fas.usda.gov/data/taiwan-taiwan-confident-food-stocks-covid-19-disruptsinternational-trade.20.4.20.

World Farmers' Organization (WFO). (2020). COVID-19: What Cambodian Farmers Are Experiencing?

https://www.wfo-oma.org/covid-19/farmers-challenges/covid-19-what-cambodian-farmers-areexperiencing/.20.4.2020. 